\title{
Implementation of a novel in vitro model of infection of reconstituted human epithelium for expression of virulence genes in methicillin-resistant Staphylococcus aureus strains isolated from catheter-related infections in Mexico
}

Gloria Luz Paniagua-Contreras', Eric Monroy-Pérez¹, Felipe Vaca-Paniagua², José Raymundo Rodríguez-Moctezuma³, Erasmo Negrete-Abascal ${ }^{1}$ and Sergio Vaca ${ }^{*}$

\begin{abstract}
Background: Methicillin-resistant Staphylococcus aureus (MRSA) are clinically relevant pathogens that cause severe catheter-related nosocomial infections driven by several virulence factors.

Methods: We implemented a novel model of infection in vitro of reconstituted human epithelium (RHE) to analyze the expression patterns of virulence genes in 21 MRSA strains isolated from catheter-related infections in Mexican patients undergoing haemodialysis. We also determined the phenotypic and genotypic co-occurrence of antibiotic- and disinfectant-resistance traits in the S. aureus strains, which were also analysed by pulsed-field-gel electrophoresis (PFGE).

Results: In this study, MRSA strains isolated from haemodialysis catheter-related infections expressed virulence markers that mediate adhesion to, and invasion of, RHE. The most frequent pattern of expression (present in $47.6 \%$ of the strains) was as follows: $f n b A, f n b B, s p a, c l f A, c l f B, c n a, b b p$, ebps, eap, sdrC, sdrD, sdrE, efb, icaA, and agr. Seventy-one percent of the strains harboured the antibiotic- and disinfectant-resistance genes ermA, ermB, tet $(M)$, tet $(K), \operatorname{blaZ}$, qacA, qacB, and qacC. PFGE of the isolated MRSA revealed three identical strains and two pairs of identical strains. The strains with identical PFGE patterns showed the same phenotypes and genotypes, including the same spa type (t895), suggesting hospital personnel manipulating the haemodialysis equipment could be the source of catheter contamination.
\end{abstract}

Conclusion: These findings help define the prevalence of MRSA virulence factors in catheter-related infections. Some of the products of the expressed genes that we detected in this work may serve as potential antigens for inclusion in a vaccine for the prevention of MRSA-catheter-related infections.

Keywords: MRSA, Haemodialysis catheter, Virulence factors

\section{Introduction}

Staphylococcus aureus is a bacterial pathogen that causes multiple infections in humans, ranging from superficial skin infections to endocarditis, bone and joint infections, septic shock [1], and severe haemodialysis catheter-related infections [2]. S. aureus produce a broad spectrum of extracellular and cell wall-associated virulence determinants that

\footnotetext{
* Correspondence: vacasergio@gmail.com

${ }^{1}$ FES-Iztacala, Universidad Nacional Autónoma de México, Av. de Los Barrios 1, Los Reyes Iztacala, Tlalnepantla, 54090, Edo. de México, México

Full list of author information is available at the end of the article
}

contribute to the severity of infection [3]. Microbial adherence to cells and extracellular matrix is an essential first step in the process of colonization and infection [4], for which $S$. aureus express numerous surface adhesins known as microbial surface components recognizing adhesive matrix molecules (MSCRAMMs). These adhesins mediate adherence to host extracellular matrix components such as fibrinogen, fibronectin, and collagen [5]. Pathogenic adhesins include Fibronectin-binding protein $\mathrm{A}$ and B (FnBPA and FnBPB); Staphylococcus protein A (Spa); clumping factor A (ClfA); clumping factor B (ClfB); collagen 
adhesion (Cna); sialoprotein-binding protein (Bbp); elastinbinding protein of Staphylococcus aureus (EbpS); extracellular adhesion protein (Eap); serine aspartate repeat proteins C, D, and E (SdrC, SdrD, and SdrE; [3]); and extracellular fibrinogen-binding protein (Efb; [6]). Furthermore, pathogenic $S$. aureus strains exhibit a great capacity for biofilm formation on surfaces, making endovascular catheters a favourable niche for infection. Biofilm formation requires synthesis of PNAG (polymeric N-acetylglucosamine); the enzymes responsible for its synthesis are encoded by the ica $A D B C$ operon [7]. Expression of most virulence factors in $S$. aureus is controlled by the agr locus [8].

The number of methicillin-resistant $S$. aureus (MRSA) strains has steadily increased and nosocomial infections caused by MRSA have become a serious problem worldwide, as its presence has dramatically reduced the number of effective antibiotics available for the prevention and treatment of infections in hospitals and communities [9]. The main mechanism of methicillin resistance involves expression of the mecA gene, which encodes penicillinbinding protein $2 \mathrm{a}(\mathrm{PBP} 2 \mathrm{a})$, a transpeptidase with low affinity for $\beta$-lactams [10]. MRSA strains frequently carry genes for multidrug resistance such as blaZ, which codes $\beta$-lactamases and confers resistance to $\beta$-lactams; erm $A$, erm $B$, and erm $C$ confer erythromycin resistance; aac(69)Ie-aph(20)-Ia confers aminoglycoside resistance; tet $(M)$, tet $(O)$, and tet $(K)$ confer resistance to tetracycline; and $v a n A$ and $v a n B$ confer vancomycin resistance [11]. Widespread use of quaternary ammonium compounds (QAC) in hospitals contributes to the selection of disinfectantresistant $S$. aureus [12]. In several staphylococcal species, the $q a c A, q a c B$, and $q a c C$ genes have been identified in plasmids that also contain antibiotic-resistance genes [13-15].

The expression of virulence factors of $S$. aureus has been studied in vivo in animal models of infection [16,17], but immune cellular factors and nutritional conditions have affected the expression of virulence determinants. To circumvent these problems, in this study we propose a novel model of infection in vitro of reconstituted human epithelium (RHE) to analyze the expression patterns of virulence genotypes of MRSA strains isolated from catheter-related infections in Mexican patients undergoing haemodialysis. We also determined the phenotypic and genotypic combinations of antibiotic- and disinfectantresistance in the $S$. aureus strains, which also were analysed by pulsed-field-gel electrophoresis (PFGE).

\section{Materials and methods}

\section{Bacterial strains}

Twenty-one $S$. aureus strains were donated by the Laboratorio Clínico de la Facultad de Estudios Superiores Iztacala (Universidad Nacional Autónoma de México) for phenotypic and molecular analysis. These strains were isolated from catheter-related infections of ambulatory patients
( $\mathrm{n}=21$ ) undergoing treatment at a public hospital in Estado de México, México from January to May 2013. The bacterial strains were identified by classical microbiologic methods: Gram staining; mannitol, catalase, and coagulase activity (Bactident-coagulase, Merck); and the Api 32 Staph test (BioMerieux). S. aureus strains were molecularly characterized by PCR amplification of $23 \mathrm{~S}$ rRNA, coagulase (coa), thermonuclease (nuc), clumping factor (clfA), protein A region X (spa), femA, and $f e m B[18,19]$. Bacterial DNA was extracted with the Wizard Genomic DNA Purification Kit (Promega). Resistance to methicillin was determined by the cefoxitin disc diffusion test (Becton Dickinson; inhibition zone, $\leq 21 \mathrm{~mm}$ ) [20]. $\beta$-Lactamase enzymes were detected by using paper discs impregnated with the chromogenic cephalosporin nitrocephin (Becton Dickinson, USA). This substrate changes from yellow to red after the amide bond of the $\beta$-lactam ring is hydrolysed by $\beta$-lactamase. The change in colour was observed from 5 min- $1 \mathrm{~h}$. The mec $A$ gene, which encodes methicillin resistance, was identified by conventional PCR [21]. $S$. aureus ATCC 25923 (mecA -) and ATCC 33592 (mecA+) were used as controls in each test.

\section{Antibiotic susceptibility testing}

The standard disc diffusion method of Kirby-Bauer in Mueller Hinton agar (Bioxon) was used to evaluate antibiotic susceptibility. Multidiscs for Gram-positive bacteria were used (Bio-Rad). Results were interpreted in accordance with Clinical and Laboratory Standards Institute guidelines [20]. The antibiotics were ampicillin (AM, $10 \mu \mathrm{g})$, cefalotin $(\mathrm{CF}, 30 \mu \mathrm{g})$, cefotaxime (CTX, $30 \mu \mathrm{g})$, levofloxacin (LEV, $5 \mu \mathrm{g})$, cefuroxime (CXM, $30 \mu \mathrm{g})$, dicloxacillin (DC, $1 \mu \mathrm{g})$, erythromycin (E, $15 \mu \mathrm{g})$, gentamycin (GE, $10 \mu \mathrm{g})$, cefepime (FEP, $30 \mu \mathrm{g}$ ), penicillin (PE, $10 \mathrm{U}$ ), tetracycline (TE, $30 \mu \mathrm{g}$ ), and trimethoprim-sulfamethoxazole (SXT, $25 \mu \mathrm{g}$ ). S. aureus ATCC 25923 (mec $A-)$ and ATCC 33592 (mec $A+)$ strains were used as controls in each test.

\section{Detection of antibiotic and disinfectant resistance genes}

The tet(M), tet(O), tet(K), vanA, vanB, aac(69)-Ie-aph(20)Ia and blaZ genes were identified by PCR as described by Rizzotti et al. [11] and ermA, ermB, erm C, msrA, mef, qacA, $q a c B$, and $q a c C$ as described by Zmantar et al. [12].

\section{SCCmec types and agr groups}

A multiplex PCR with four primer pairs was used to identify the five main known SCCmec types [22] and another multiplex PCR with five primers was used to identify the agr groups [23].

\section{RHE inoculation with S. aureus}

Reconstituted human epithelium (RHE; SkinEthic Laboratories, Nice, France) consists of human epithelial cell lines cultured on polycarbonate filters in vitro at the air-liquid 
interface in serum-free chemically defined medium. A total of $2 \times 10^{6} \mathrm{~S}$. aureus cells suspended in $50 \mu \mathrm{L}$ PBS were inoculated onto the surface of the RHE and incubated at $37^{\circ} \mathrm{C}$ for $72 \mathrm{~h}$ with $5 \% \mathrm{CO}_{2}$ and saturated humidity. The maintenance media was changed every $24 \mathrm{~h}$.

\section{S. aureus RNA purification and reverse transcription}

S. aureus cells were harvested from the RHE and suspended in $1 \mathrm{~mL}$ RNA Protect Bacteria Reagent (Qiagen). The sample was vortexed $30 \mathrm{~s}$ and incubated at room temperature $5 \mathrm{~min}$. After centrifugation at $9400 \mathrm{rpm}$ for $10 \mathrm{~min}$, the cells were resuspended in $200 \mu \mathrm{L}$ TE buffer $(10 \mathrm{mM}$ Tris- $\mathrm{HCl}, 1 \mathrm{mM}$ EDTA, pH 8) containing $10 \mathrm{mg} / \mathrm{mL}$ lysozyme and $40 \mathrm{mg} / \mathrm{mL}$ lysostaphin. The sample was vortexed $10 \mathrm{~s}$ and incubated at room temperature $5 \mathrm{~min}$. Total RNA was purified with the RN easy Mini Kit (Qiagen) according to the manufacturer's instructions, including DNase treatment. The concentration and purity of total RNA were analysed with a NanoDrop 2000 spectrophotometer (Thermo Scientific). cDNA synthesis was performed with the QuantiTec Reverse transcription kit (Qiagen) according to the manufacturer's instructions.

\section{Real-Time PCR amplification}

The primers for Real-Time PCR were described previously as follows: fnbA, fnbB, spa, clfA, clfB, cna, bbp, ebpS, eap, $S d r C$, $s d r D$, $s d r E$, and $e f b$ [3]; and $a g r$ [24]. The Rotor-Gene SYBR Green PCR kit (Qiagen) was used for Real-Time PCR expression profiling of icaA [25] and $\operatorname{gyr} B$ (reference gene; [26]) using a Rotor Gene Probe PCR Kit (Qiagen). S. epidermidis ATCC 35984 and Escherichia coli ATCC 11775 were used as negative controls. S. aureus ATCC 33592 was used as the positive control.

\section{PFGE typing}

MRSA isolates were PFGE typed by preparation of DNA and resolution of the SmaI-digested fragments as described by McDougal et al. [27]. Samples were separated on a CHEF-DR II system (Bio-Rad). Gels were photographed and digitized using a Bio-Rad Gel Doc. PFGE patterns were analysed as described by Tenover et al. [28] for bacterial strain typing.

\section{Data analysis}

PFGE patterns were analysed with Gene Tool and Gene Directory software (Syngene). Reference standard S. aureus NCTC 8325 was included in each gel for band normalization. Percent similarities were obtained from the weighted pair group with mathematical average (UPMGA) based on Dice coefficients. Band position tolerance was set at $1.25 \%$. A similarity coefficient of $80 \%$ was selected to define the pulsed-field type clusters.

\section{spa typing}

The polymorphic $\mathrm{X}$ region of the protein A coding gene (spa) was amplified and sequenced as described [29]. Corresponding spa-types were assigned using the SPA Searcher website (http://seqtools.com). Ridom spa types were subsequently assigned using the spa-typing website (http://www.spaserver.ridom.de/) developed by Ridom Gmb.

\section{Results}

All $S$. aureus strains $(\mathrm{n}=21)$ were resistant to methicillin (Table 1). All MRSA strains ( $\mathrm{n}=21)$ expressed $7 / 15$ studied genes: spa, clfB cna, $b b p$, $s d r C$, icaA, and $a g r$. [group II $(\mathrm{n}=18)$; group I $(\mathrm{n}=3)$ ] during in vitro infection of RHE (Table 2); $95.2 \%(\mathrm{n}=20)$ expressed $s d r D$ and $e f b$; 90.4\% ( $\mathrm{n}=19)$ expressed fubA, clfA, ebps, and eap; $85.7 \%$ $(\mathrm{n}=18)$ expressed $s d r E$; and $80.9 \%(\mathrm{n}=17)$ expressed fubB.

Without considering the 7 genes expressed by all MRSA strains, ten distinct expression patterns of virulence markers were found during MRSA infection of RHE in vitro (Table 3). Pattern 1 , formed by the other 8 studied genes (fnbA, fnbB, clfA, ebps, eap, sdrD, sdrE, ebf) was present in ten $(\mathrm{n}=47.7 \%)$ MRSA isolates, whereas patterns 2 and 3, both composed of 7 genes each, were expressed by two strains. The other seven patterns were constituted by 4-7 genes and were expressed only by one MRSA strain (Table 3).

PFGE analysis showed that MRSA strains were distributed in 15 distinct electrophoretic patterns (data not shown). MRSA strains S-22 and S-36 (Table 2), isolated from the catheters of different patients, have identical electrophoretic patterns (data not shown) and the same spa type as the S-59 and S-66 MRSA strains (spa type t895). Three strains isolated from different patients showed $100 \%$ similarity by PFGE (S-77, S-79, S-82; Table 2) and belonged to the same spa type $\mathrm{t} 895$. Two closely related strains (S-8 and S108) were isolated from the catheters of two different patients and two possibly related strains (S-16 and S-19) were isolated from two different patients. The strains with identical PFGE patterns (S-22 and S-36; S-59 and S-66; S-77, S-79 and S-82) showed the same phenotypes and genotypes (Table 1 ). The most frequent spa types were t895 $(76.2 \% ; \mathrm{n}=16)$ and t008 $(14.2 \% ; \mathrm{n}=3$; Table 2).

All MRSA strains were resistant to erythromycin (E), ampicillin (AM), tetracycline (TE), and penicillin (PE; Table 1). The frequency of resistance to other antibiotics tested was: cefotaxime (CTX) 95.2\%, $\mathrm{n}=20$; dicloxacillin (DC) 95.2\%, $\mathrm{n}=20$; cefepime (FEP) 90.5\%, $\mathrm{n}=19$; cefuroxime (CXM) 66.7\%, $\mathrm{n}=14$; cefalotin (CF) $62 \%$, $\mathrm{n}=13$; levofloxacin (LEV) 57.1\%, $\mathrm{n}=12$; trimethoprimsulfamethoxazole (SXT) $14.3 \%, \mathrm{n}=3$; and gentamycin (GE) $14.3 \%, \mathrm{n}=3$ (Table 1 ). All MRSA strains were $\beta$-lactamase producers (Table 1). The following patterns of antibiotic resistance were found: 5 antibiotics (1 strain), 6 antibiotics ( 2 strains), 7 antibiotics ( 5 strains), 9 antibiotics (1 strain), 
Table 1 Antibiotic-resistance phenotypes and PCR detection of genes encoding antibiotic and disinfectant resistance in the MRSA strains

\begin{tabular}{|c|c|c|c|}
\hline $\begin{array}{l}\text { Antibiotic-resistance } \\
\text { phenotypes }\end{array}$ & $\begin{array}{l}\beta \text { - lact } \\
\text { amase } \\
\text { PROD }\end{array}$ & $\begin{array}{l}\text { Antibiotic- resistance } \\
\text { genotypes }\end{array}$ & $\begin{array}{c}\text { Disinfectant } \\
\text { resistance } \\
\text { genotypes }\end{array}$ \\
\hline
\end{tabular}
Strain SCCmec Cefoxitin CF LEV E AM TE SXT CTX GE CXM FEP DC PE ermA ermB ermC mrsA mef tet tet tet vanA vanB aac(69) blaZ qacA qacB qacC (MRSA)

(M) (O) (K) le-aph

\begin{tabular}{|c|c|c|c|c|c|c|c|c|c|c|c|c|c|c|c|c|c|c|c|c|c|c|c|c|c|c|c|c|c|c|}
\hline & & & & & & & & & & & & & & & & & & & & & & & & & & & & & & \\
\hline S-58 & \multirow[t]{3}{*}{1} & $\mathrm{R}$ & $\mathrm{R}$ & $\mathrm{R}$ & $\mathrm{R}$ & $\mathrm{R}$ & $\mathrm{R}$ & $\mathrm{R}$ & $\mathrm{R}$ & R & $\mathrm{R}$ & $\mathrm{R}$ & $\mathrm{R}$ & $\mathrm{R}$ & + & + & + & - & - & - & + & - & + & - & - & + & + & + & + & + \\
\hline S-76 & & $\mathrm{R}$ & $\mathrm{S}$ & $\mathrm{S}$ & $\mathrm{R}$ & $\mathrm{R}$ & $\mathrm{R}$ & $S$ & $S$ & $S$ & $S$ & $\mathrm{~S}$ & $\mathrm{R}$ & $\mathrm{R}$ & + & + & + & - & - & - & + & - & + & - & - & - & + & - & - & + \\
\hline S-106 & & $R$ & $\mathrm{R}$ & $\mathrm{R}$ & $R$ & $R$ & $R$ & $S$ & $\mathrm{R}$ & $S$ & $R$ & $\mathrm{R}$ & $R$ & $R$ & + & + & + & - & - & - & + & - & + & - & - & - & + & + & + & + \\
\hline S-10 & \multirow[t]{6}{*}{$\|$} & $\mathrm{R}$ & $\mathrm{R}$ & $\mathrm{R}$ & $\mathrm{R}$ & $\mathrm{R}$ & $\mathrm{R}$ & $S$ & $\mathrm{R}$ & $S$ & $\mathrm{R}$ & $\mathrm{R}$ & $\mathrm{R}$ & $\mathrm{R}$ & + & + & + & - & - & - & + & - & + & - & - & - & + & + & + & + \\
\hline S-59 & & $\mathrm{R}$ & $\mathrm{R}$ & $\mathrm{R}$ & $\mathrm{R}$ & $\mathrm{R}$ & $\mathrm{R}$ & S & $\mathrm{R}$ & $S$ & $\mathrm{R}$ & $\mathrm{R}$ & $\mathrm{R}$ & $\mathrm{R}$ & + & + & + & - & - & - & + & - & + & - & - & - & + & - & - & + \\
\hline S-66 & & $\mathrm{R}$ & $\mathrm{R}$ & $\mathrm{R}$ & $R$ & $\mathrm{R}$ & $R$ & $S$ & $\mathrm{R}$ & $S$ & $R$ & $\mathrm{R}$ & $\mathrm{R}$ & $\mathrm{R}$ & + & + & + & - & - & - & + & - & + & - & - & - & + & - & - & + \\
\hline S-73 & & $\mathrm{R}$ & $S$ & $S$ & $\mathrm{R}$ & $\mathrm{R}$ & $\mathrm{R}$ & $S$ & $\mathrm{R}$ & $S$ & $S$ & $\mathrm{R}$ & $S$ & $\mathrm{R}$ & + & + & + & + & - & - & + & - & + & - & - & - & + & + & + & + \\
\hline S-75 & & $R$ & $R$ & $\mathrm{R}$ & $R$ & $R$ & $R$ & $S$ & $\mathrm{R}$ & $S$ & $R$ & $\mathrm{R}$ & $R$ & $\mathrm{R}$ & + & + & + & - & - & - & + & - & + & - & - & - & + & - & - & + \\
\hline S-108 & & $R$ & $R$ & $S$ & $R$ & $R$ & $R$ & $S$ & $R$ & $R$ & $R$ & $R$ & $R$ & $R$ & + & + & + & + & - & - & + & - & + & - & - & + & + & + & + & + \\
\hline S-16 & \multirow[t]{12}{*}{ IV } & $R$ & $S$ & $S$ & $R$ & $R$ & $R$ & $S$ & $R$ & $S$ & $S$ & $S$ & $R$ & $R$ & + & + & + & - & - & - & + & - & + & - & - & - & + & - & - & + \\
\hline S-19 & & $\mathrm{R}$ & $\mathrm{R}$ & $\mathrm{R}$ & $R$ & $\mathrm{R}$ & $R$ & $S$ & $\mathrm{R}$ & $R$ & $R$ & $\mathrm{R}$ & $\mathrm{R}$ & $\mathrm{R}$ & + & + & + & - & - & - & + & - & + & - & - & + & + & + & + & + \\
\hline $\mathrm{s}-22$ & & $\mathrm{R}$ & $\mathrm{R}$ & $\mathrm{R}$ & $\mathrm{R}$ & $\mathrm{R}$ & $\mathrm{R}$ & $\mathrm{R}$ & $\mathrm{R}$ & $S$ & $\mathrm{R}$ & $\mathrm{R}$ & $\mathrm{R}$ & $\mathrm{R}$ & + & + & + & - & - & - & + & - & + & - & - & - & + & + & + & + \\
\hline S-36 & & $\mathrm{R}$ & $\mathrm{R}$ & $\mathrm{R}$ & $\mathrm{R}$ & $\mathrm{R}$ & $\mathrm{R}$ & $\mathrm{R}$ & $\mathrm{R}$ & $S$ & $\mathrm{R}$ & $\mathrm{R}$ & $\mathrm{R}$ & $\mathrm{R}$ & + & + & + & - & - & - & + & - & + & - & - & - & + & + & + & + \\
\hline S-52 & & $R$ & $\mathrm{R}$ & $\mathrm{R}$ & $R$ & $R$ & $R$ & $S$ & $R$ & $S$ & $R$ & $R$ & $R$ & $R$ & + & + & + & - & - & - & + & - & + & - & - & - & + & + & + & + \\
\hline S-77 & & $R$ & $S$ & $S$ & $R$ & $R$ & $R$ & $S$ & $R$ & $S$ & 5 & $R$ & $R$ & $R$ & + & + & + & - & - & - & + & - & + & - & - & - & + & + & + & + \\
\hline S-79 & & $\mathrm{R}$ & $S$ & $S$ & $\mathrm{R}$ & $\mathrm{R}$ & $\mathrm{R}$ & $S$ & $\mathrm{R}$ & $S$ & $S$ & $\mathrm{R}$ & $\mathrm{R}$ & $\mathrm{R}$ & + & + & + & - & - & - & + & - & + & - & - & - & + & + & + & + \\
\hline S-82 & & $\mathrm{R}$ & $\mathrm{S}$ & $\mathrm{S}$ & $\mathrm{R}$ & $\mathrm{R}$ & $\mathrm{R}$ & $S$ & $\mathrm{R}$ & $S$ & $S$ & $\mathrm{R}$ & R & $\mathrm{R}$ & + & + & + & - & - & - & + & - & + & - & - & - & + & + & + & + \\
\hline S-93 & & $\mathrm{R}$ & $S$ & $S$ & $R$ & $\mathrm{R}$ & $R$ & $S$ & $\mathrm{R}$ & $S$ & $\mathrm{R}$ & $R$ & $S$ & $\mathrm{R}$ & + & + & + & - & - & - & + & - & + & - & - & - & + & + & + & + \\
\hline S-103 & & $R$ & $\mathrm{R}$ & $\mathrm{R}$ & $R$ & $\mathrm{R}$ & $R$ & $S$ & $R$ & $S$ & $R$ & $\mathrm{R}$ & $\mathrm{R}$ & $\mathrm{R}$ & + & + & + & - & - & - & + & - & + & - & - & - & + & + & + & + \\
\hline S-107 & & $\mathrm{R}$ & $S$ & $S$ & $\mathrm{R}$ & $R$ & $\mathrm{R}$ & $S$ & $\mathrm{R}$ & $S$ & $S$ & $\mathrm{R}$ & $\mathrm{R}$ & $\mathrm{R}$ & + & + & + & - & - & - & + & - & + & - & - & - & + & + & + & + \\
\hline S-8 & & $\mathrm{R}$ & $\mathrm{R}$ & $\mathrm{R}$ & $\mathrm{R}$ & $\mathrm{R}$ & $R$ & $S$ & $\mathrm{R}$ & $S$ & $\mathrm{R}$ & $\mathrm{R}$ & $S$ & $\mathrm{R}$ & + & + & + & - & - & - & + & - & + & - & - & - & + & + & + & + \\
\hline $\begin{array}{l}\text { No. of } \\
\text { resistant } \\
\text { strains }\end{array}$ & & 21 & 13 & 12 & 21 & 21 & 21 & 3 & 20 & 3 & 14 & 19 & 20 & 21 & 21 & 21 & 21 & 2 & 0 & 0 & 21 & 0 & 21 & 0 & 0 & 3 & 21 & 16 & 16 & 21 \\
\hline
\end{tabular}


Table 2 Expression of virulence genes, spa typing, and PFGE in the MRSA strains

\begin{tabular}{|c|c|c|c|c|c|c|c|c|c|c|c|c|c|c|c|c|c|}
\hline Strain & $f n b A$ & $f n b B$ & spa & clfA & CIfB & cna & $b b p$ & ebps & eap & sdrC & $s d r D$ & sdrE & $e f b$ & icaA & agr Group & spa typing & *PFGE \\
\hline S-10 & + & + & + & + & + & + & + & + & + & + & + & + & + & + & II & t895 & $1^{\mathrm{A}}$ \\
\hline S-16 & + & + & + & + & + & + & + & + & + & + & + & + & + & + & $\|$ & t002 & $2^{B}$ \\
\hline S-19 & + & + & + & + & + & + & + & + & + & + & + & - & + & + & $\|$ & t895 & \\
\hline $\mathrm{S}-22$ & + & + & + & + & + & + & + & + & + & + & + & + & + & + & II & t895 & $3^{c}$ \\
\hline $\mathrm{S}-36$ & + & + & + & + & + & + & + & + & + & + & + & + & + & + & II & t895 & \\
\hline S-52 & - & + & + & - & + & + & + & + & + & + & + & + & + & + & II & t895 & $4^{A}$ \\
\hline S-58 & + & + & + & - & + & + & + & + & + & + & + & - & + & + & $\|$ & t895 & $5^{A}$ \\
\hline S-59 & + & + & + & + & + & + & + & + & + & + & + & + & + & + & II & t895 & $6^{c}$ \\
\hline S-66 & + & + & + & + & + & + & + & + & + & + & + & + & + & + & II & t895 & \\
\hline S-73 & - & + & + & + & + & + & + & + & + & + & + & + & + & + & II & t008 & $7^{A}$ \\
\hline S-75 & + & - & + & + & + & + & + & + & + & + & + & + & + & + & I & t895 & $8^{A}$ \\
\hline S-76 & + & - & + & + & + & + & + & + & + & + & + & + & + & + & II & t189 & $9^{A}$ \\
\hline S-77 & + & + & + & + & + & + & + & + & + & + & + & + & + & + & $\|$ & t895 & $10^{C}$ \\
\hline S-79 & + & + & + & + & + & + & + & + & + & + & + & + & + & + & $\|$ & t895 & \\
\hline S-82 & + & + & + & + & + & + & + & + & + & + & + & + & + & + & $\|$ & t895 & \\
\hline S-93 & + & + & + & + & + & + & + & - & + & + & + & + & + & + & II & t008 & $11^{\mathrm{A}}$ \\
\hline S-103 & + & + & + & + & + & + & + & + & - & + & + & + & + & + & 1 & t895 & $12^{\mathrm{A}}$ \\
\hline S-106 & + & - & + & + & + & + & + & - & + & + & + & + & + & + & $\|$ & t895 & $13^{A}$ \\
\hline S-107 & + & - & + & + & + & + & + & + & - & + & - & + & - & + & 1 & t008 & $14^{\mathrm{A}}$ \\
\hline S-8 & + & + & + & + & + & + & + & + & + & + & + & - & + & + & $\|$ & t895 & $15^{\mathrm{D}}$ \\
\hline S-108 & + & + & + & + & + & + & + & + & + & + & + & + & + & + & $\|$ & t895 & \\
\hline No & 19 & 17 & 21 & 19 & 21 & 21 & 21 & 19 & 19 & 21 & 20 & 18 & 20 & 21 & 21 & & \\
\hline$\%$ & 90.4 & 80.9 & 100 & 90.4 & 100 & 100 & 100 & 90.4 & 90.4 & 100 & 95.2 & 85.7 & 95.2 & 100 & 100 & & \\
\hline
\end{tabular}

${ }^{*} A=$ Different, $B=$ Possibly related, $C=$ Identical and $D=$ Closely related

10 antibiotics (8 strains), 11 antibiotics (3 strains), and 12 antibiotics (1 strain) (Table 1).

Type IV SCCmec was identified by PCR in 12 MRSA strains, whereas type II SCCmec was detected in 6 strains, and type I SCCmec in 3 strains (Table 1). The ermA and ermB genotypes were identified in all strains, whereas erm $C$ was detected only in S-73. All strains carried the tet $(M)$, tet(K), and blaZ genes. The aac(69)-Ie- aph(20)-Ia gene was identified in gentamycin-resistant strains $\mathrm{S}-19$, S-58, and S-108 (Table 2). The mrsA, mef, tet(O), vanA, and $v a n B$ antibiotic resistance genes were not identified in any of the MRSA strains.

Our evaluation of disinfectant resistance revealed 100\% $(\mathrm{n}=21)$ of the MRSA strains carried qacC, 76\% $(\mathrm{n}=16)$ carried $q a c A$, and $76 \%(\mathrm{n}=16)$ carried qacB. Fifteen strains (71.4\%) showed the same phenotype/genotype pattern:

Table 3 *Patterns of gene expression in the MRSA strains

\begin{tabular}{|c|c|c|c|}
\hline Pattern $\mathrm{N}^{\circ}$ & Expressed genes of the MRSA strains $(n=21)$ & $\mathrm{N}^{\circ}$ of strains $(\%)$ & $\mathrm{N}^{\circ}$ of genes per pattern $(n=15)$ №.\% \\
\hline 1 & $f \cap b A, f n b B, c l f A, e b p s$, eap, sdrD, sdrE, efb & $10(47.7)$ & $15(100)$ \\
\hline 2 & $f n b A, c l f A$, ebps, eap, sdrD, sdrE, efb & $2(9.5)$ & $14(93.3)$ \\
\hline 3 & $f \cap b A, f \cap b B, c l f A$, ebps, eap, sdrD, efb & $2(9.5)$ & $14(93.3)$ \\
\hline 4 & $f n b B, c l f A, e b p s, e a p, s d r D, s d r E$, efb & $1(4.7)$ & $14(93.3)$ \\
\hline 5 & $f \cap b A, f \cap b B, c l f A, e a p, s d r D, s d r E$, efb & $1(4.7)$ & $14(93.3)$ \\
\hline 6 & $f \cap b A, f n b B, c l f A, e b p s, s d r D, s d r E$, efb & $1(4.7)$ & $14(93.3)$ \\
\hline 7 & $f n b B$, ebps, eap, sdrD, sdrE, efb & $1(4.7)$ & $13(86.6)$ \\
\hline 8 & $f \cap b A, f n b B$, ebps, eap, sdrD, efb & $1(4.7)$ & $13(86.6)$ \\
\hline 9 & $f n b A, c l f A$, eap, sdrD, sdrE, efb & $1(4.7)$ & $13(86.6)$ \\
\hline 10 & $f \cap b A, c l f A, e b p s, s d r E$ & $1(4.7)$ & $11(73.3)$ \\
\hline
\end{tabular}

*Without considering the 7 genes expressed by all strains (spa, clfb, cna, bbp, sdrC, icaA, and agr). fnbA/B=Fibronectin-binding protein $A / B$; clfA=clumping factor $A$; ebps=elastin-binding protein; eap=extracellular adhesion protein; $s d r D / E=S$ erin aspartate repeat protein $D / E ; ~ e f b=E x t r a c e l l u l a r$ fibrinogen binding protein. 
resistance to erythromycin, ampicillin, tetracycline, cefotaxime, penicillin, $\beta$-lactamase production/ermA, $\operatorname{ermB}$, tet $(M)$, tet(K), blaZ, qacA, qacB, and qacC positivity.

\section{Discussion}

Haemodialysis patients who are infected with methicillinresistant Staphylococcus aureus (MRSA) are considered to have healthcare-associated (HA) infections [30,31].

For colonization and infection, bacterial adhesion to host extracellular matrix components like fibrinogen, fibronectin, and collagen is essential [5]. Therefore, there has been a strong interest in studying the involvement of proteins of the MSCRAMMs family of $S$. aureus using in vivo and in vitro models of infection [32-35]. In this study we implemented a novel model of infection in vitro of reconstituted human epithelium (RHE) to analyze the expression patterns of the MSCRAMMs family adhesion genes, and icaA and agr in S. aureus strains isolated from catheter-related infections in Mexican patients subjected to haemodialysis. Our data show that most of the genes that we studied were expressed by MRSA after infection of RHE (Table 2), which reflects the pathogenic behaviour of these strains. We identified ten different patterns of expression (Table 3), of which pattern No. 1, represented by the 15 genes studied (fnbA, fnbB, spa, clfA, clfB, cna, $b b p$, ebps, eap, sdrC, sdrD, sdrE, efb, icaA, agr), was present in ten MRSA strains (47.7\%; Table 3). These results show that during infection of RHE, the MRSA strains expressed 11 to 13 genes coding for bacterial surface proteins; icaA, which participates in biofilm formation [7]; and the agr locus, which is a global regulator of multiple virulence factors [8]. These findings are consistent with the notion that pathogenesis of most $S$. aureus infections cannot be explained by the action of an unique virulence factor, but by several distinct factors acting in concert during the infective process [36]. Cna has been associated with endocarditis [37] and keratitis [38]. Fibronectin-binding proteins mediate adherence to human airway epithelium [4]. Clumping factor A (ClfA) plays an antiphagocytic role in neutrophils and macrophages [39] and is necessary for infection/pathogenesis in in vivo models of arthritis, sepsis, and endocarditis $[40,41]$. Clumping factor B (ClfB) mediates respiratory infection and attachment to cytokeratins on nasal epithelial cells [42] and the role of protein A (Spa) in $S$. aureus virulence has been demonstrated in models of sepsis and pneumonia [43]. Although the precise role of Sdr adhesins in staphylococcal infection is unknown, a strong correlation between the $s d r$ genes of $S$. aureus and certain diseases has been reported. There is a significantly increased prevalence of the $s d r E$ gene in invasive $S$. aureus strains [44], in S. aureus strains responsible for osteomyelitis [45] and in S. aureus isolates responsible for bone infections [46]. A recent report noted that Eap is associated with invasive diseases [33].
Earlier findings suggested a possible relationship between particular agr groups with the capacity of MRSA to cause specific illnesses. The $a g r$ I and $a g r$ II strains are associated with suppurative infections; agr III is associated with toxic shock syndrome toxin (TSST-1) mediated disease, and $a g r$ IV is associated with exfoliative toxin- and impetigo-producing strains [47]. Consistent with these findings, the strains reported in this work were isolated from suppurative catheter-related infections, or initiating suppurative catheter-related infections, and carried agrII $(85.7 \%, \mathrm{n}=18)$ or agr I $(14.3 \%, \mathrm{n}=3$; Table 2$)$.

Most of the strains reported here carried the SCCmec type IV $(57 \%, n=12$; Table 1$)$, an allele initially considered to be a characteristic of community-acquired MRSA (CA-MRSA; [48]). However, MRSA infections in dialysisdependent patients have been considered to be mainly HA (healthcare-associated) according to epidemiologic classifications [49], and there are several reports of MRSA strains harbouring SCCmec type IV in HA infections [30,31,50-52]. The increase in multiple drug-resistant (MDR) MRSA has become a major challenge for the treatment of infectious diseases caused by what are known as superbugs. Strikingly, all the strains reported here were multidrug resistant $\beta$-lactamase producers. They were resistant to 5 to 12 antibiotics. None of the strains was sensitive to erythromycin, ampicillin, tetracycline, or penicillin (Table 1). On the other hand, only three strains (14.3\%) were resistant to sulfamethoxasole/ Trimethoprim or gentamycin. The high frequency of resistance to these antibiotics may reflect the fact that physicians of the public health service in Mexico prescribe all of these antibiotics, which are considered essential drugs in this sector.

The most frequent combination of antibiotic- and disinfectant-resistance phenotype/genotype in the MRSA strains $(71.4 \%, \mathrm{n}=15)$ was: resistance to erythromycin, ampicillin, tetracycline, cefotaxime, penicillin, and $\beta$ lactamase production in association with $\operatorname{erm} A$, ermB, tet $(M)$, tet $(K)$, blaz, qacA, qacB, and qacC genotypes (Table 1). These strains are not only resistant to five antibiotics, but also harbour three of the six plasmidencoded MDR efflux pumps which mediate resistance to several biocides such as antimicrobial organic cations, including intercalating dyes (e.g., acriflavine and ethidium bromide), and quaternary ammonium compounds (e.g., benzalkonium chloride; [53]). Staphylococcal strains resistant to disinfectant have been identified in clinical isolates of MRSA from China (62\%; [54]), Taiwan (55.4\%; [55]), and Hong Kong (42\%; [56]). All the erythromycin-resistant MRSA strains reported here carried the ermA and ermB genes and two strains (S-73 and S-108) carried the ermC gene. The $m s r A$ and $m e f$ genes were not detected in either strain (Table 1). We did not find discordances between the presence of erm genes and phenotypic resistance to 
erythromycin, as has been reported in other studies [12,57]. The incidence of ermA genes in our MRSA strains (100\%) is higher than those reported in erythromycin-resistant $S$. aureus: $7.7 \%$ in Tunisia [12] and 16\% in Denmark [58].

All MRSA strains were resistant to tetracycline and possessed the tet $(M)$ and tet $(K)$ genes (Table 1$)$. Tetracycline is an antibiotic commonly used in Mexico to treat human and animal bacterial infections, contributing to the selection and propagation of resistant strains. Tetracycline resistance in S. aureus is encoded by the pT181 plasmid [59] and the tet ( $M$ ) gene can be found in combination with ermB in the Tn916 transposon. The simultaneous presence of these genes has been found frequently in enterococci, as well as in streptococci and staphylococci [60]. Consistent with this, all the strains studied here carried these two genes, suggesting the presence of these genetic elements in the MRSA we analysed.

The gene aac(69)-Ie-aph(20)-Ia was detected in three strains (S-19, S-58, and S-108) that were also resistant to gentamycin; the $v a n A$ and $v a n B$ genes were not detected in any MRSA strain.

The strains with identical PFGE patterns showed the same phenotypes, genotypes, and spa type, suggesting that hospital personnel manipulating the haemodialysis equipment could be the cause of catheter contamination by these strains.

Our results are relevant because they demonstrate that MRSA strains isolated from catheter-related infections in haemodialysis patients express several virulence markers involved in the adhesion and invasion of RHE. We also analysed the phenotypes and genotypes of antibiotics and disinfectant resistance. These results will help define the incidence of virulence factors in MRSA associated with catheter-related infections and improve therapies in haemodialysis patients. In addition, some of the products of the expressed genes that we detected in this work may serve as potential antigens for inclusion in a vaccine for the prevention of MRSA-catheter-related infections.

\section{Competing interests}

The authors declare that they have no competing interests.

\section{Authors' contributions}

GLPC, EMP, JRRM and ENA have made substantial contributions to acquisition of data. FVP has made substantial contributions to analysis and interpretation of data. SV has been involved in drafting the manuscript and has given final approval of the version to be published. All authors have read and approved the manuscript.

\section{Acknowledgement}

This project was supported through the PAPCA № 7 2013, FES-Iztacala, Universidad Nacional Autónoma de México.

\section{Author details}

${ }^{1}$ FES-Iztacala, Universidad Nacional Autónoma de México, Av. de Los Barrios 1, Los Reyes Iztacala, Tlalnepantla, 54090, Edo. de México, México. ${ }^{2}$ Instituto Nacional de Cancerología, Laboratorio de Genómica, México, DF, México. ${ }^{3}$ Instituto Mexicano del Seguro Social, G. Baz esq. F. Gómez, Tlalnepantla, Estado de México, México.
Received: 26 October 2013 Accepted: 22 December 2013

Published: 9 January 2014

\section{References}

1. Diekema DJ, Pfaller MA, Schmitz FJ, Smayevsky J, Bell J, Jones RN, Beach M: Survey of infections due to Staphylococcus species: frequency of occurrence and antimicrobial susceptibility of isolates collected in the United States, Canada, Latin America, Europe, and the Western Pacific region for the SENTRY Antimicrobial Surveillance Program, 1997-1999. Clin Infect Dis 2001, 32(Suppl 2):S114-S132

2. Viale P, Stefani S: Vascular catheter-associated infections: a microbiological and therapeutic update. J Chemother 2006, 18:235-249.

3. Campbell SJ, Deshmukh HS, Nelson CL, Bae IG, Stryjewski ME, Federspiel Jנ, Tonthat GT, Rude TH, Barriere SL, Corey R, Fowler VG Jr: Genotypic characteristics of Staphylococcus aureus isolates from a multinational trial of complicated skin and skin structure infections. J Clin Microbiol 2008, 46:678-684.

4. Mongodin E, Bajolet O, Cutrona J, Bonnet N, Du-puit F, Puchelle E, de Bentzmann S: Fibronectin-binding proteins of Staphylococcus aureus are involved in adherence to human airway epithelium. Infect Immun 2002, 70:620-630

5. Navarre W, Schneewind O: Surface proteins of Gram-positive bacteria and mechanisms of their targeting to the cell wall envelope. Microbiol Mol Biol Reviews 1999, 63:174-229.

6. Lee LY, Liang $X$, Hook M, Brown EL: Identification and characterization of the C3 binding domain of the Staphylococcus aureus extracellular fibrinogen- binding protein (Efb). J Biol Chem 2004, 279:50710-50716.

7. Götz F: Staphylococcus and Biofilms. Mol Microbiol 2002, 43:1367-1378.

8. Ji G, Beavis RC, Novick RP: Cell density control of staphylococcal virulence mediated by an octapeptide pheromone. Proc Natl Acad Sci USA 1995, 92:12055-12059.

9. Gould IM: The clinical significance of methicillin-resistant Staphylococcus aureus. J Hosp Infect 2005, 61:277-282.

10. Hartman BJ, Tomasz A: Low-affinity penicillin-binding protein associated with beta-lactam resistance in Staphylococcus aureus. J Bacteriol 1984 158:513-516.

11. Rizzotti L, Simeoni D, Cocconcelli P, Gazzola S, Dellaglio F, Torriani S: Contribution of enterococci to the spread of antibiotic resistance in the production chain of swine meat commodities. J Food Prot 2005, 68:955-965

12. Zmantar T, Kouidhi B, Miladi H, Bakhrouf A: Detection of macrolide and disinfectant resistance genes in clinical Staphylococcus aureus and coagulase-negative staphylococci. BMC Res Notes 2011, 4:453.

13. Anthonisen IL, Sunde M, Steinum TM, Sidhu MS, Sorum H: Organization of the antiseptic resistance gene qacA and Tn552-related $\beta$-lactamase genes in multidrug-resistant Staphylococcus haemolyticus strains of animal and human origins. Antimicrob Agents Chemother 2002, 46:3606-3612

14. Mayer S, Boos M, Beyer A, Flui AC, Schmitz FJ: Distribution of the antiseptic resistance genes qacA, qacB and qacC in 497 methicillin resistant and susceptible European isolates of Staphylococcus aureus. J Antimicrob Chemother 2001, 47:896-897.

15. Sidhu MS, Heir $E$, Sorum $H$, Holck A: Genetic linkage between resistance to quaternary ammonium compounds and $\beta$ lactam antibiotics in food related Staphylococccus spp. Microb Drug Resis 2001, 7:363-371.

16. Burian $M$, Rautenberg $M$, Kohler T, Fritz M, Krismer B, Unger C, Hoffmann WH, Peschel A, Wolz C, Goerke C: Temporal expression of adhesion factors and activity of global regulators during establishment of Staphylococcus aureus nasal colonization. J Infect Dis 2010, 201:1414-1421.

17. Montgomery CP, Boyle-Vavra S, Adem PV, Lee JC, Husain AN, Clasen J, Daum RS: Comparison of virulence in community associated methicillin-resistant Staphylococcus aureus pulsotypes USA300 and USA400 in a rat model of pneumonia. J Infect Dis 2008, 198:561-570.

18. Kobayashi N, Wu H, Kojima K, Taniguchi K, Urasawa S, Uehara N, Omizu Y, Kishi $Y$, Yagihashi A, Kurokawa I: Detection of $\operatorname{mec} A$, fem $A$ and fem $B$ genes in clinical strains of staphylococci using polymerase chain reaction. Epidemiol Infect 1994, 113:259-266.

19. Nashev D, Toshkova K, Salasia ISO, Hassan AA, Lämmler C, Zschöck M: Distribution of virulence genes of Staphylococcus aureus isolated from stable nasal carriers. FEMS Microbiol Lett 2004, 233:45-52. 
20. CLSI: Performance Standards for Antimicrobial Susceptibility Testing, Twenty-Third Informational Supplement M100-S23. Wayne, PA: Clinical and Laboratory Standards Institute; 2013.

21. Geha DJ, Uhl JR, Gustaferro CA, Persing DH: Multiplex PCR for identification of methicillin-resistant staphylococci in the clinical laboratory. J Clin Microbiol 1994, 32:1768-1772.

22. Boye K, Bartels MD, Andersen IS, Møller JA, Westh HA: New multiplex PCR for easy screening of methicillin-resistant Staphylococcus aureus SCCmec types I-V. Clin Microbiol Infect 2007, 13:725-727.

23. Gilot $P$, Lina $G$, Cochard T, Poutrel B: Analysis of the genetic variability of genes encoding the RNA III-activating components Agr and TRAP in a population of Staphylococcus aureus strains isolated from cows with mastitis. J Clin Microbiol 2002, 40:4060-4067.

24. van Leeuwen $W$, van Nieuwenhuizen $W$, Gijzen $C$, Verbrugh $H$, Van Belkum A: Population studies of methicillin-resistant and sensitive Staphylococcus aureus strains reveal a lack of variability in the agrD gene, encoding a staphylococcal autoinducer peptide. J Bacterio 2000, 182:5721-5729

25. Valle J, Toledo-Arana A, Berasain C, Ghigo JM, Amorena B, Penades JR, Lasa I: SarA and not $\sigma B$ is essential for biofilm development by Staphylococcus aureus. Mol Microbiol 2003, 48:1075-1087.

26. Beenken KE, Dunman PM, McAleese F, Macapagal D, Murphy E, Projan SJ, Blevins JS, Smeltzer MS: Global gene expression in Staphylococcus aureus biofilms. J Bacteriol 2004, 186:4665-4684.

27. McDougal LK, Steward CD, Killgore GE, Chaitram JM, McAllister SK, Tenover FC: Pulsed-field gel electrophoresis typing of oxacillin-resistant Staphylococcus aureus isolates from the United States: Establishing a National Database. J Clin Microbiol 2003, 41:5113-5120.

28. Tenover FC, Arbeit RD, Goering RV, Mickelsen PA, Murray BE, Persing DH, Swaminathan B: Interpreting chromosomal DNA restriction patterns produced by pulsed-field gel electrophoresis: criteria for bacterial strain typing. J Clin Microbiol 1995, 33:2233-2239.

29. Shopsin B, Gomez M, Montgomery SO, Smith DH, Waddington M, Dodge DE, Bost DA, Riehman M, Naidich S, Kreiswirth BN: Evaluation of protein A gene polymorphic region DNA sequencing for typing of Staphylococcus aureus strains. J Clin Microbiol 1999, 37:3556-3563.

30. Johnson LB, Venugopal AA, Pawlak J, Saravolatz LD: Emergence of community-associated methicillin-resistant Staphylococcus aureus infection among patients with end-stage renal disease. Infect Control Hosp Epidemiol 2006, 27:1057e62.

31. Johnson LB, Jose J, Yousif F, Pawlak J, Saravolatz LD: Prevalence of colonization with community-associated methicillin resistant Staphylococcus aureus among end-stage renal disease patients and healthcare workers. Infect Control Hosp Epidemiol 2009, 30:4e8.

32. Bur S, Preissner KT, Herrmann M, Bischoff M: The Staphylococcus aureus extracellular adherence protein promotes bacterial internalization by keratinocytes independent of fibronectin-binding proteins. J Invest Dermatol 2013, 133:2004-2012.

33. Edwards AM, Bowden MG, Brown EL, Laabei M, Massey RC: Staphylococcus aureus extracellular adherence protein triggers TNFa release, promoting attachment to endothelial cells via protein A. PLoS One 2012, 7:e43046.

34. Oogai $Y$, Matsuo M, Hashimoto M, Kato F, Sugai M, Komatsuzawa H: Expression of virulence factors by Staphylococcus aureus grown in serum. Appl Environ Microbiol 2011, 77:8097-8105.

35. Veloso TR, Chaouch A, Roger T, Giddey M, Vouillamoz J, Majcherczyk P, Que YA, Rousson V, Moreillon P, Entenza JM: Use of a human-like low-grade bacteremia model of experimental endocarditis to study the role of Staphylococcus aureus adhesins and platelet aggregation in early endocarditis. Infect Immun 2013, 81:697-703.

36. Peacock SJ, Day NPJ, Thomas MG, Berendt AR, Foster TJ: Clinical isolates of Staphylococcus aureus exhibit diversity in $\mathrm{fnb}$ genes and adhesion to human fibronectin. J Infection 2000, 41:23-31.

37. Hienz SA, Schennings T, Heimdahl A, Flock J: Collagen binding of Staphylococcus aureus is a virulence factor in experimental endocarditis. $\mathrm{J}$ Infect Dis 1996, 174:83-88.

38. Rhem MN, Lech EM, Patti JM, McDevitt D, Hook M, Jones DB, Wilhelmus KR: The collagen-binding adhesin is a virulence factor in Staphylococcus aureus keratitis. Infect Immun 2000, 68:3776-3779.

39. Higgins J, Loughman A, van Kessel KP, van Strijp JA, Foster TJ: Clumping factor A of Staphylococcus aureus inhibits phagocytosis by human polymorphonuclear leucocytes. FEMS Microbiol Lett 2006, 258:290-296.
40. Josefsson E, Hartford O, O'Brien L, Patti JM, Foster T: Protection against experimental Staphylococcus aureus arthritis by vaccination with clumping factor A, a novel virulence determinant. J Infect Dis 2001, 184:1572-1580.

41. Vernachio J, Bayer AS, Le T, Chai YL, Prater B, Schneider A, Syribeys P, Robbins J, Patti JM: Anti-clumping factor $A$ immunoglobulin reduces the duration of methicillin-resistant Staphylococcus aureus bacteremia in an experimental model of infective endocarditis. Antimicrob Agents Chemother 2003, 47:3400-3406.

42. O'Brien LM, Walsh EJ, Massey RC, Peacock SJ, Foster TJ: Staphylococcus aureus clumping factor $\mathrm{B}$ (ClfB) promotes adherence to human type cytokeratin 10: implications for nasal colonization. Cell Microbiol 2002, 4:759-770.

43. Bubeck WJ, Patel RJ, Schneewind O: Surface proteins and exotoxins are required for the pathogenesis of Staphylococcus aureus pneumonia. Infect Immun 2007, 75:1040-1044.

44. Peacock SJ, Moore CE, Justice A, Kantzanou M, Story L, Mackie K, O'Neill G, Day NP: Virulent combinations of adhesin and toxin genes in natural populations of Staphylococcus aureus. Infect Immun 2002, 70:4987-4996.

45. Sabath A, Melles DC, Martirosian G, Grundmann H, van Belkum A, Hryniewicz W: Distribution of the serine-aspartate repeat protein encoding sdr genes among nasal and invasive Staphylococcus aureus strains. J Clin Microbio/ 2006, 44:1135-1138.

46. Trad S, Allignet J, Frangeul L, Davi M, Vergassola M, Couve E, Morvan A, Kechrid A, Buchrieser C, Glaser P, El-Solh N: DNA macroarray for identification and typing of Staphylococcus aureus isolates. J Clin Microbiol 2004, 42:2054-2064.

47. Jarraud S, Mougel C, Thioulouse J, Lina G, Meugnier H, Forey F, Nesme X, Etienne J, Vandenesch F: Relationships between Staphylococcus aureus genetic background, virulence factors, agr groups (alleles), and human disease. Infect Immun 2002, 70:631-641.

48. Deurenberg $\mathrm{RH}$, Vink C, Kalenic S, Friedrich AW, Bruggeman CA, Stobberingh EE: The molecular evolution of methicillin-resistant Staphylococccus aureus. Clin Microbiol Infect 2007, 13:222-235.

49. Buck JM, Como-Sabetti K, Harriman KH, Danila RN, Boxrud DJ, Glennen A, Lynfield R: Community-associated methicillin-resistant Staphylococcus aureus, Minnesota, 2000-2003. Emerg Infect Dis 2005, 11:1532-1538.

50. Centers for Disease Control and Prevention (CDC): Invasive methicillin-resistant Staphylococcus aureus infections among dialysis patients United States, 2005 MMWR Morb Mortal Wkly Rep 2007, 56:197-199.

51. Lin CC, Wang JL, Lin CY, Chen SY, Wang JT, Wu KD: Methicillin-resistant Staphylococcus aureus bacteremia in patients with end-stage renal disease in Taiwan: distinguishing between community-associated and healthcare-associated strains. Infect Control Hosp Epidemiol 2009, 30:89-92.

52. Strandén AM, Frei R, Adler H, Flückiger U, Widmer AF: Emergence of SCCmec type IV as the most common type of methicillin-resistant Staphylococcus aureus in a university hospital. Infection 2009, 37:44-48.

53. Littlejohn TG, Paulsen IT, Gillespie MT, Tennent JM, Midgley M, Jones IG, Purewal AS, Skurray RA: Substrate specificity and energetics of antiseptic and disinfectant resistance in Staphylococcus aureus. FEMS Microbiol Lett 1992, 74:259-265.

54. Wang C, Cai P, Zhan Q, Mi Z, Huang Z, Chen G: Distribution of antiseptic-resistance genes $q a c A / B$ in clinical isolates of methicillinresistant Staphylococcus aureus in China. J Hosp Infect 2008, 69:393-394

55. Wang JT, Sheng WH, Wang JL, Chen D, Chen ML, Chen YC, Chang SC: Longitudinal analysis of chlorhexidine susceptibilities of nosocomial methicillin-resistant Staphylococcus aureus isolates at a teaching hospital in Taiwan. J Antimicrob Chemother 2008, 62:514-517.

56. Zhang M, O'Donoghue MM, Ito T, Hiramatsu K, Boost MV: Prevalence of antiseptic-resistance genes in Staphylococcus aureus and coagulase-negative staphylococci colonizing nurses and the general population in Hong Kong. J Hosp Infect 2011, 8:113-117.

57. Sekiguchi J, Hama T, Fujino T, Araake M, Irie A, Saruta K, Konosaki H, Nishimura H, Kawano A, Kudo K, Kondo T, Sasazuki T, Kuratsuji T, Yoshikura H, Kirikae T: Detection of the antiseptic- and disinfectantresistance genes $q a c A, q a c B$, and $q a c C$ in methicillin-resistant Staphylococcus aureus isolated in a Tokyo hospital. Jpn J Infect Dis 2004, 57:288-291. 
58. Westh H, Hougaard DM, Vuust J, Rosdahl VT: erm genes in erythromycin resistant Staphylococcus aureus and coagulase-negative staphylococci. APMIS 1995, 103:225-232.

59. Ito T, Okuma K, Ma XX, Yuzawa H, Hiramatsu K: Insights on antibiotic resistance of Staphylococcus aureus from its whole genome: genomic island SCC. Drug Resist Update 2003, 6:41-52.

60. Chopra I, Roberts M: Tetracycline antibiotics: mode of action, applications, molecular biology and epidemiology of bacterial resistance. Microbiol Mol Biol 2001, 65:232-260.

doi:10.1186/1476-0711-13-6

Cite this article as: Paniagua-Contreras et al:: Implementation of a novel

in vitro model of infection of reconstituted human epithelium for expression

of virulence genes in methicillin-resistant Staphylococcus aureus strains iso-

lated from catheter-related infections in Mexico. Annals of Clinical Microbiology and Antimicrobials 2014 13:6.

\section{Submit your next manuscript to BioMed Central and take full advantage of:}

- Convenient online submission

- Thorough peer review

- No space constraints or color figure charges

- Immediate publication on acceptance

- Inclusion in PubMed, CAS, Scopus and Google Scholar

- Research which is freely available for redistribution 